\title{
Extra corporeal carbon dioxide removal: A reliable modality in refractory hypercapnia to prevent invasive ventilation
}

\author{
Atiharsh Mohan Agarwal, Tapas Kumar Singh ${ }^{1}$
}

\section{Introduction}

Extracorporeal carbon dioxide removal $\left(\mathrm{ECCO}_{2} \mathrm{R}\right)$ is a partial form of extracorporeal lung assist (ECLA), which can be used in the management of refractory hypercapnic respiratory failure. ${ }^{[1]}$ It is a valid alternative to consider in hypercapnic respiratory failure in chronic obstructive pulmonary disease (COPD) patients to avoíd invasive ventilation when noninvasive ventilation fails. ${ }^{[2]}$

Here we report a similar case, after obtaining informed consent, where a patient suffering from severe hypercapnic respiratory failure due to COPD, was selected for $\mathrm{ECCO}_{2} \mathrm{R}$ and improved remarkably.

\section{Case Report}

We present a case report of a 73 -year-old male $(91.5 \mathrm{~kg}$, height $-184 \mathrm{~cm}$ ) referred to our hospital with acute on

\section{From:}

Department of Intensive Care, James Cook University Hospital,

Middlesbrough, UK, ${ }^{1}$ Department of Anaesthesiology and Critical Care,

Sarojini Naidu Medical College, Agra, Uttar Pradesh, India

\section{Correspondence:}

Dr. Atiharsh Mohan Agarwal, Department of Anaesthesiology and Critical Care, Sarojini Naidu Medical College, Agra, Uttar Pradesh, India

E-mail: atiharsh1982@gmail.com

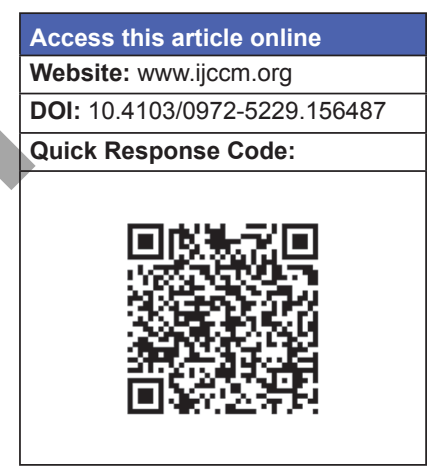

chronic COPD exacerbation and Type 2 respiratory failure not responding to conventional nonivasive ventilation. Later patient developed multiple organ dysfunction syndrome with Type 2 respiratory failure with mixed acidosis.

His presenting blood gases showed profound acidemia. $\mathrm{pH}$ - 7.057, base excess - 7.5, $\mathrm{PCO}_{2}-11.23 \mathrm{kPa}$, $\mathrm{PaO}_{2}-13.7 \mathrm{kPa}$ on $\mathrm{FiO}_{2}-50 \%$. P: $\mathrm{F}$ ratio was around 200. His inflammatory markers were high (total leukocyte count [TLC] $26 \times 10^{9} / \mathrm{L}$, procalcitonin $11.2 \mathrm{mcg} / \mathrm{L}$, C-reactive protein [CRP] $104 \mathrm{mg} / \mathrm{L}$ ) and renal functions worsened and he was oliguric.

He was started on appropriate antibiotics and noninvasive ventilation. He was started on noradrenaline infusion to target mean arterial pressure of $70 \mathrm{~mm} \mathrm{Hg}$. Continuous veno-venous hemodiafiltration instituted to manage his renal failure with an aim for a negative fluid balance of $1.5 \mathrm{~L}$. Hemodynamic monitoring was done by pulse-induced contour cardiac output.

After $12 \mathrm{~h}$, he continued to be acidotic profoundly because of raised $\mathrm{PaCO}_{2}-10.86 \mathrm{kPa}$. Failure to remove $\mathrm{CO}_{2}$ was noted despite being on non-invasive ventilation. His chest was clear B/L on auscultation. His vasopressors 